\title{
Research on the Application of Contactless Intelligent Express Cabinet
}

\author{
Hongxia $\mathrm{Lu}^{1, *}$ \\ ${ }^{1}$ College of Management, Wuhan Donghu University, Wuhan, 430212, China
}

\begin{abstract}
Because of the COVID-19 epidemic situation, the advantages of intelligent express cabinet stand out, compared with the traditional terminal distribution. It can not only solve the problem of terminal delivery difficulty but also that of the user privacy assurance, in which the contactless delivery becomes deeply popular because cross-infection is avoided. This paper studies the domestic present situation of the application of intelligent express cabinet and the existing problems, according to the data of 207 copies of questionnaires, analyses the consumer cognition and attitude towards intelligent express cabinet. In order to expand the application market of intelligent express cabinets, the paper puts forward measures such as integrating resources, improving the utilization rate, investigating the needs, reasonable layout, integrating community services, and enriching the profit model.
\end{abstract}

\section{Introduction}

In the era of mobile Internet, the rapid development of Ecommerce and logistics industry has brought great convenience to consumers. According to the statistics of the State Post Bureau, the national express delivery volume reached 63.52 billion units in 2019, with an incremental scale of more than 10 billion units for two consecutive years, which ranked the forefront of modern service industry and became an important driving force in economic growth. With the increasing volume of express delivery, intelligent express cabinets are more widely used. Because of COVID-19 contactless delivery, intelligent express cabinets have become more popular among consumers.

Scholars have done related research on intelligent express cabinets. E Morganti, L Dablanc, F Fortin(2014)Research on final deliveries for online shopping: The deployment of pickup point networks in urban and suburban areas. The paper shows that at the French national level, PPs are now a well established alternative to home deliveries and their presence covers urban, suburban and rural areas ${ }^{[1]}$. Ying Zheng(2016) Analysis of measures on difficulties of express management to the community property in the environment of online shopping. She thinks that the introduction of intelligent express cabinets can not only improve the quality of express delivery service, but also create a complete community property service platform ${ }^{[2]}$. Yumin Li, LuYang, Xinlu Wang (2017) Research on evolutionary game analysis on cooperation mechanism of express enterprises and third-party smart express cabinet enterprises, an evolutionary game model of express enterprises and third-party smart express cabinet enterprises was established in this paper ${ }^{[3]}$. Bo Wei (2019) Research on selection and configuration optimization of intelligent express cabinets based on K-Means cluster analysis, he investigates the delivery situation of courier in different regions and uses SPSS software to perform Kmeans clustering to obtain the size ratio of cabinets for express cabinets in different regions to meet the various demands of customers ${ }^{[4]}$. ZiangMA, Kebin Jia (2020) Research on high performance intelligent express cabinet management system based on WEB, they puts forward the design of Web intelligent express cabinet management system which integrates cabinet management, operation and maintenance personnel management, investor management, advertising plan auditing and advertising plan publishing. The actual application results of the system verify the effectiveness ${ }^{[5]}$.From the point of research literature, domestic for the research of intelligent express ark starts late, still stay in the surface layer of phenomenon description and countermeasures, not thorough, the content is messy, not form a system, the results of the study is relatively loose, research method and theory, quantitative analysis and model is less. In this paper, by means of questionnaire survey data for smart people express the ark of the cognitive and attitude to analyze the application of non-contact intelligent express ark, the study of the intelligent express ark is a kind of supplement.

\section{Application Status of Intelligent Express Cabinet in China}

In 2019, the number of intelligent express delivery cabinets in major cities reached 406000 groups, and the rate of express delivery entering cabinets in 2020 is

*Author's e-mail: luhx@wdu.edu.cn 
expected to reach 15 percent. In 2019, the top 10 of the intelligent express cabinets are Lejia, Fengchao, China Post Express, Jiangsu Cloud Cabinet, Jinlinbao, Gage Warehouse, Transitive Intelligence, No .1 Cabinet, Postal Treasure. etc. According to the investigation, $74 \%$ of users in the country can use the collection service. In general, the application of intelligent express cabinets can help achieve the purpose of user privacy protection, Free pickup time and the safer effect without any contact. The figure 1 shows the market application of intelligent express cabinets from 2015 to 2019.

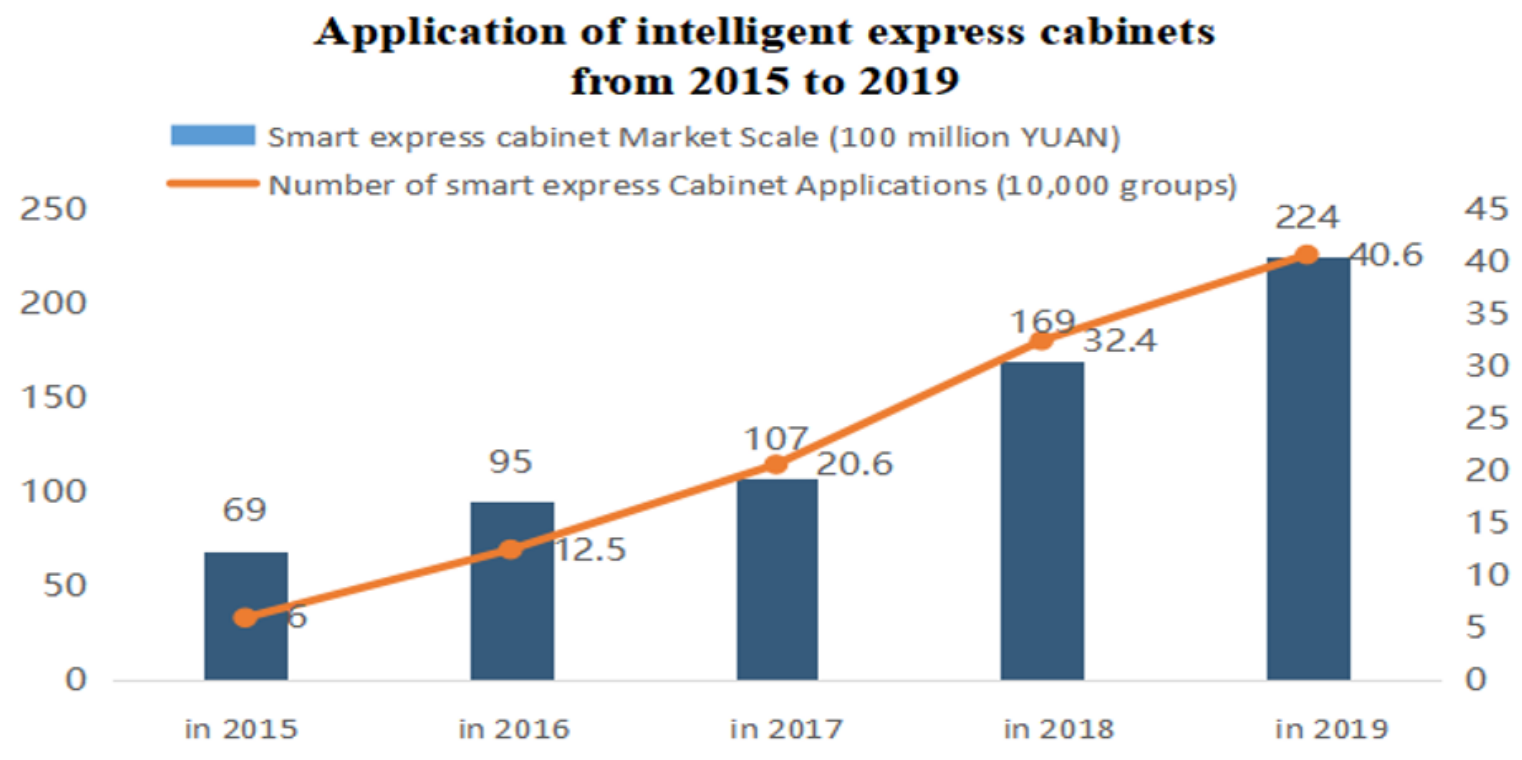

Figure 1. Application of intelligent express cabinets from 2015 to 2019

\section{Problems of Intelligent Express Cabinet Application}

In recent years, the application of Intelligent express cabinets is called a dose of "good medicine" to solve the "last 100 meter gap " between the reality and ideal, but the following problems still exist:

- The utilization rate of the cabinet is not high because of several reasons, one of which is that customer is used to "wait for express delivery ", or take express from Cainiao post station, another of which is that the size and number of intelligent express cabinets are limited, so as to be difficult for the cabinet to cope with large packages and deal with "Double 11" online package volume surge.

- Unstable performance leads to the result that intelligent express cabinet has missed text messages, input verification code does not open the door, wrong door, and a sudden drop can be shown in the customer experience.

- Unreasonable layout can be seen in such several aspects as not taking into account the population density and demand for online shopping, some areas of excessive and some areas of insufficient delivery.

- The convenience is insufficient. The way of sending and receiving parts is not humanized to use the smart phone whose operation is more complicated and the needs of the elderly retirees are not taken into account.

- The profit model is single. The hardware money investment of intelligent express cabinet is high, so the cost of a group of intelligent cabinet is as high as 18,000 to 60,000 . Even more, the cost of maintenance is $5-7$ million a year, but the consumer takes the piece free and is charged about 0.5 yuan for express delivery.

- The security can not be guaranteed and it is not convenient for the public to use intelligent express delivery cabinets to collect fragile and valuable items. There is no clear explanation of the responsibility once the items are lost or damaged.

\section{Consumer's Cognition and Attitude Analysis of Intelligent Express Cabinet}

The data of this study are mainly from field survey and network survey. Field investigation is mainly in the population of residential areas and the areas near colleges and universities. The network survey is published on the questionnaire star website. In this study, 207 valid questionnaires have been collected, and the samples are reasonably distributed in the dimensions of sex, age, education level, residence and so on, as shown in Table 1.

Table 1. Demographic distribution

\begin{tabular}{llllllll}
\hline Category & $\begin{array}{l}\text { Individual } \\
\text { characteristics }\end{array}$ & $\begin{array}{l}\text { Number } \\
\text { of persons }\end{array}$ & $\begin{array}{l}\text { Percentage } \\
(\mathbf{\%})\end{array}$ & Category & $\begin{array}{l}\text { Individual } \\
\text { characteristics }\end{array}$ & $\begin{array}{l}\text { Number of } \\
\text { persons }\end{array}$ & $\begin{array}{l}\text { Percentage } \\
(\%)\end{array}$ \\
\hline Gender & Male & 80 & 38.65 & Vocational & Enterprise employees & 38 & 18.36
\end{tabular}




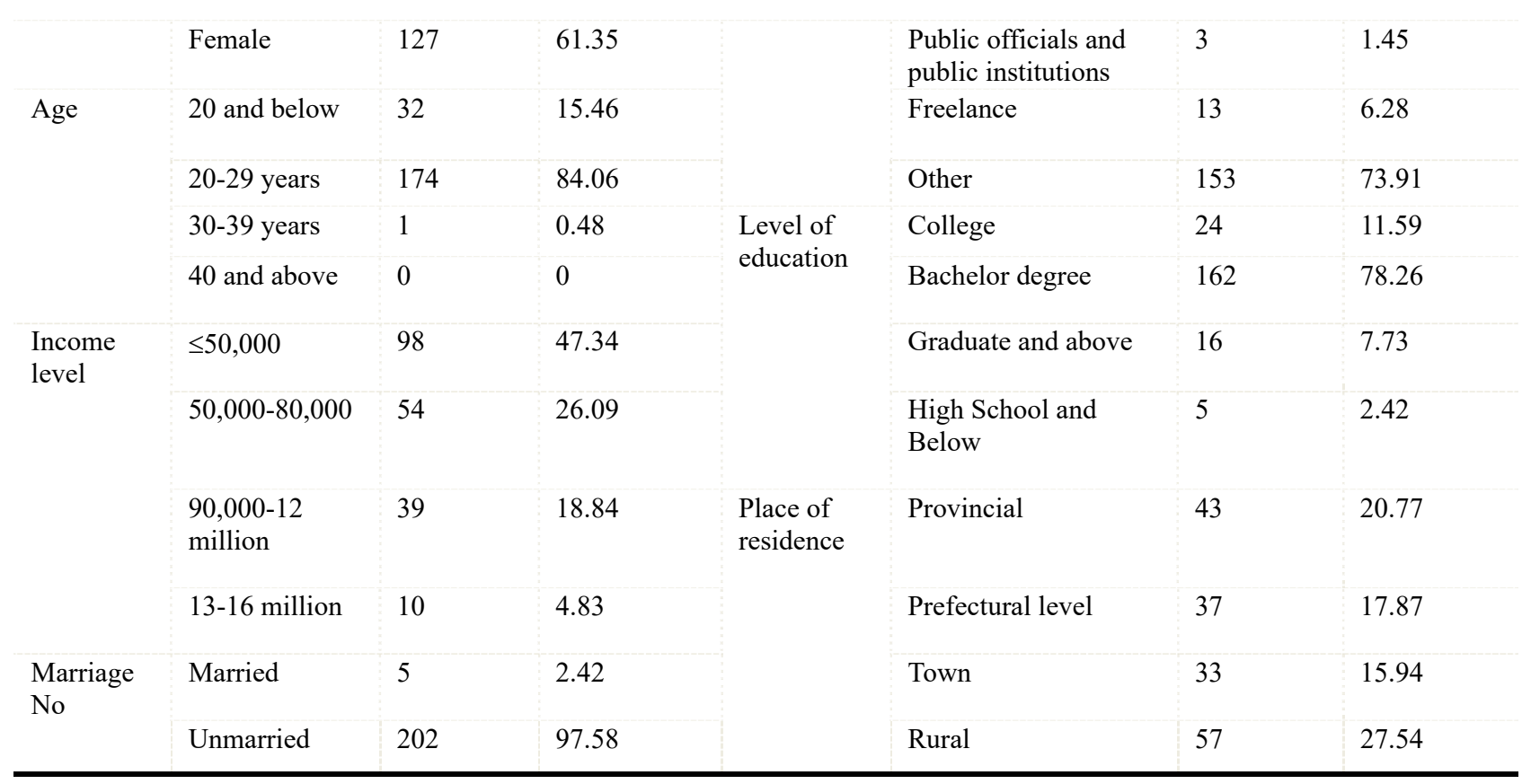

Table 1 shows that the ratio of men to women in the sample is close to $1: 2$. The population surveyed is concentrated in the 20-29 age group and under 20, A total of $99.52 \%$ of the survey population. The $20-29$ age group is mostly composed of college students and new entrants with more acceptance of new things, at the same time who are also the main force of online shopping. In terms of income levels, the annual income of the respondents is mainly about 50,000 yuan and below $47.34 \%$. In terms of education, most of them are undergraduates, the proportion is $78.26 \%$.

Table 2. Awareness and Expectation of Smart Express Cabinets

\begin{tabular}{|c|c|c|c|c|c|c|c|}
\hline Issues & Variable & $\begin{array}{c}\text { Number of } \\
\text { persons }\end{array}$ & $\begin{array}{l}\text { Percent } \\
\text { age (\%) }\end{array}$ & Issues & Variable & $\begin{array}{c}\text { Number of } \\
\text { persons }\end{array}$ & $\begin{array}{l}\text { Percentage } \\
(\%)\end{array}$ \\
\hline \multirow{3}{*}{$\begin{array}{l}\text { Have you } \\
\text { been } \\
\text { exposed }\end{array}$} & $\begin{array}{l}\text { Regular } \\
\text { exposure }\end{array}$ & 30 & 14.49 & \multirow[t]{3}{*}{$\begin{array}{l}\text { Willingness } \\
\text { to use }\end{array}$} & Very willing & 105 & 50.72 \\
\hline & $\begin{array}{l}\text { Occasional } \\
\text { contact }\end{array}$ & 80 & 38.65 & & Willingness & 91 & 43.96 \\
\hline & No contact & 97 & 46.86 & & Not willing & 3 & 1.45 \\
\hline \multirow[t]{5}{*}{ Focus } & Cost & 142 & 68.6 & \multirow{3}{*}{$\begin{array}{l}\text { Charging } \\
\text { attitude }\end{array}$} & It doesn't matter & 8 & 3.86 \\
\hline & $\begin{array}{l}\text { Location of } \\
\text { pick-up }\end{array}$ & 159 & 76.81 & & Not acceptable & 45 & 73.43 \\
\hline & $\begin{array}{l}\text { ease } \\
\text { operation }\end{array}$ & 90 & 43.48 & & Are acceptable & 4 & 1.93 \\
\hline & Output Speed & 91 & 43.96 & & $\begin{array}{l}\text { Reasonable } \\
\text { acceptability }\end{array}$ & 152 & 73.43 \\
\hline & Other & 43 & 20.77 & & It doesn't matter & 6 & 2.9 \\
\hline \multirow[t]{4}{*}{ Prospects } & Very & 72 & 35.27 & \multirow[t]{4}{*}{ Convenience } & Very convenient & 114 & 55.07 \\
\hline & There should be & 125 & 60.39 & & General & 86 & 41.55 \\
\hline & No & 4 & 1.93 & & No convenience & 3 & 1.45 \\
\hline & I don't know & 5 & 2.42 & & It doesn't matter & 4 & 1.93 \\
\hline \multirow{4}{*}{$\begin{array}{l}\text { Recomme } \\
\text { ndations }\end{array}$} & Safety & 148 & 71.5 & & & & \\
\hline & $\begin{array}{l}\text { Simple } \\
\text { operation }\end{array}$ & 144 & 69.57 & & & & \\
\hline & $\begin{array}{l}\text { Close pick-up } \\
\text { point }\end{array}$ & 165 & 79.71 & & & & \\
\hline & Free use & 98 & 47.34 & & & & \\
\hline
\end{tabular}

It can be seen from Table 2 that $46.86 \%$ of the people have never been in contact with the intelligent express 
cabinet, which shows that the intelligent express cabinet has a large development space, and the degree of people's willingness to use the intelligent express cabinet is as high as $94.68 \%$. The survey shows that the people have high expectations for the cabinet.

From the point of view of charging attitude, the proportion of the people that can accept the charge of intelligent express delivery cabinet reaches $75.36 \%$. From the suggestions given by them, we can see that $79.71 \%$ want express mail closer, which shows that consumers pay attention to the cost and convenience of using intelligent express delivery cabinet. From the perspective of consumers' attitude towards fees, the proportion of people who can accept the fees of intelligent express cabinets reaches $75.36 \%$. As for the charge of intelligent express cabinets, $73.43 \%$ of consumers think the price is reasonable and acceptable. As can be seen from the suggestions given by consumers, $79.71 \%$ of them hope that the pick-up point is near, indicating that consumers are very concerned about the cost and convenience of intelligent express cabinets. The number of consumers who are willing to use and think that intelligent express cabinets have development prospects reaches $85.66 \%$, indicating that intelligent express cabinets have great development potential.

Table 3. An Analysis of People's Attitude to Service Evaluation and Willingness to Use Smart Express Cabinets

\begin{tabular}{llllll}
\hline $\mathbf{X} \backslash \mathbf{Y}$ & Very willing & Willingness & Not willing & It doesn't matter & Subtotal \\
\hline Satisfied & $9(56.25 \%)$ & $5(31.25 \%)$ & $2(12.50 \%)$ & $0(0 \%)$ & 16 \\
Satisfactory & $58(51.33 \%)$ & $50(44.25 \%)$ & $1(0.88 \%)$ & $4(3.54 \%)$ & 113 \\
General & $36(51.43 \%)$ & $30(42.86 \%)$ & $0(0 \%)$ & $4(5.71 \%)$ & 70 \\
Not satisfied & $2(25 \%)$ & $6(75 \%)$ & $0(0 \%)$ & $0(0 \%)$ & 8 \\
\hline
\end{tabular}

As can be seen from Table 3, people who are not satisfied with traditional express service are willing to accept the use of smart express cabinets. $94.29 \%$ of those who are generally satisfied with the traditional express service are willing and very willing to use intelligent express cabinet, only $5.71 \%$ of the people do not care. Compared with those who are satisfied with the traditional express service and very satisfied, we find that the proportion of the people unwilling to use intelligent express cabinet is only $0.88 \%, 12.50 \%$. They fully show that intelligent express cabinets have a good development prospects.

To sum up, consumers focus on the stable performance of intelligent express cabinets, the degree of easy operation, whether it is convenient to pick up pieces, the level of fees and so on. The consumers generally think that intelligent express cabinets will bring convenience to life.

\section{Countermeasures and Suggestions for Accelerating the Application of Intelligent Express Cabinet}

In order to solve the problem that consumers just say "yes" to smart express cabinets without taking advantages of them, we can start from the following aspects:

- The first is to integrate resources to increase utilization. In the way that consumers can really benefit from the service, we can change their negative behavior of waiting for the express service. The benefit includes adding some large or valuables cabinets, giving full play to the full effect of the self-lifting model, etc. To build the resource integration platform of intelligent express cabinets is to achieve resource sharing, system arbitrary docking.

- The Second is to set standards and do research on product stability so that we can use norms and standards to monitor quality to improve consumer experience and solve the problems in the process of mailing items. Speed up the development of better intelligent express cabinets with more stable performance, more complete functions.

- The third is to do research on the needs and reasonable layout. The logistics enterprises in the delivery of intelligent express cabinets should survey consumers' occupancy in the proposed layout of the area, online shopping behavior and intelligent express cabinet demand, layout location and the distance between demanders, and later maintenance or after-sales work.

- The fourth is to apply new technologies to simplify operations. That's to say, fully consider the needs of consumers of all ages, including the especial usage habits of the elderly on intelligent products, simplification of the operation process and sound, or face brushing and other ways to pick up pieces.

- The fifth is to Integrate the new technology into community services so as to enrich the profit model. Such as the innovative commercial mode of express service, the mode of receiving goods under the experience line, the mode of third party substitute investment platform, the mode of drainage of $\mathrm{O} 2 \mathrm{O}$ business circle and the mode of public delivery platform. At the same time, it is necessary to further excavate and extend the value-added chain of intelligent express delivery cabinet. We can expand the community comprehensive service business, such as bus card, water, electricity self-service recharge and open temporary storage services, including community Ecommerce to buy more food, Meituan excellent selection, Shihui Tuan and all kinds of newspapers, milk delivery business. The next is to add reverse logistics services to meet the needs of consumers self-help return and exchange business. The last one is to develop media services, provide electronic screen advertising, electronic coupons, etc. to increase advertising revenue.

- The sixth is to sound measures in order to ensure safety. The relevant government departments need to improve laws and regulations, establish enterprise "integrity files" and customer "blacklists ", enterprises need to improve security measures, improve the security 
performance of intelligent express delivery, and ensure the safety of goods, Work together to create a good environment for the development of intelligent express cabinets.

\section{Acknowledgments}

This research was supported by the Youth Fund Project of Wuhan Donghu University (2017dhsk005).

\section{References}

1. Eleonora M, Laetitia D, François F. (2014) Final deliveries for online shopping: The deployment of pickup point networks in urban and suburban areas. Research in Transportation Business \& Management, 11: 23-31.

2. Zheng Ying. (2016) Online shopping environment community property to deal with express delivery management problems countermeasures analysis. Journal of Beihua University (Social Sciences Edition), 5: 23-27.

3. LI Yumin, YANG Lu, WANG Xinlu. (2017) Evolutionary Game Analysis on Cooperation Mechanism of Express Enterprises and Third-party Smart Express Cabinet Enterprises. Journal of Zhengzhou University, 9: 81-85+96.

4. Bo Wei. (2019) Research on Selection and Configuration Optimization of Intelligent Express Cabinets Based on K-Means Cluster Analysis.5th International Conference on Economics, Management, Law and Education, Hangzhou. 354357.

5. Ma Ziang, Jia Kebin. (2020) High Performance Intelligent Express Cabinet Management System Based on WEB. Computer Applications and Software, 4: $1-5+47$. 